\title{
PENGARUH IKLIM ORGANISASI DAN GAJI TERHADAP KECERDASAN EMOSIONAL GURU
}

\author{
Syamsul Bahri Tanrere ${ }^{1}$ \\ Institut PTIQ Jakarta \\ Email: s_tanrere@yahoo.com \\ Saifuddin Zuhri ${ }^{2}$ \\ Institut PTIQ Jakarta \\ Email: dzuhrie7393@gmail.com \\ Abdul Khaliqurrahman ${ }^{3}$ \\ Institut PTIQ Jakarta \\ Email: abdul.kholiq3008@gmail.com
}

\begin{abstract}
ABSTRAK
Penelitian ini bertujuan untuk mengetahui dan menguji data-data empirik terkait pengaruh iklim organisasi dan gaji terhadap kecerdasan emosional guru secara terpisah maupun simultan. Dalam penelitian ini, penulis menggunakan metode kuantitatif dengan pendekatan korelasional terhadap data-data kuantitatif yang diperoleh dari objek penelitian yaitu guru-guru sekolah yang berada di bawah naungan Yayasan Pendidikan Da'wah Ummahatul Muslimat Jakarta Timur. Sampel penelitian ini adalah sebanyak 60 responden. Pengumpulan data dilakukan dengan menggunakan teknik angket/kuesioner. Jenis analisis yang digunakan adalah analisa korelasi dan regresi yang dijabarkan secara deskriptif. Hasil dari penelitian ini adalah:

Pertama, Terdapat yang pengaruh atau koefisien korelasi sebesar 0,359, sedangkan besarnya pengaruh atau koefisien determinasi R-square sebesar 0,129 yang berarti bahwa Iklim Organisasi memberikan pengaruh terhadap Kecerdasan Emosional Guru sebesar 21,9\% dan berarti sisianya 78,1\% ditentukan oleh faktor lainnya. Untuk arah pengaruh atau koefesien regresi diperoleh $\hat{Y}=74,933+0,345 \mathrm{X}_{1}$ artinya setiap peningkatan satu unit skor Iklim Organisasi mempengaruhi peningkatan skor Kecerdasan Emosional Guru sebesar 0,345.

Kedua, Terdapat pengaruh atau koefisien korelasi sebesar 0,536 , sedangkan besarnya pengaruh atau koefisien determinasi R-square sebesar 0,288 yang berarti bahwa Gaji memberikan pengaruh terhadap Kecerdasan Emosional Guru sebesar 28,8\%
\end{abstract}


dan berarti sisianya $71,2 \%$ ditentukan oleh faktor lainnya. Untuk arah pengaruh atau koefesien regresi diperoleh $\hat{Y}=43,757+$ $0,634 \mathrm{X}_{2}$ artinya setiap peningkatan satu unit skor Iklim Organisasi mempengaruhi peningkatan skor Kecerdasan Emosional Guru sebesar 0,634.

Ketiga, terdapat pengaruh yang positif dan signifikan antara Iklim Organisasi dan Gaji secara bersama-sama terhadap Kecerdasan Emosional Guru dengan koefisien korelasi $=0,575$ dan koefisien determinasi $\mathrm{R}^{2}$ sebesar 0,331 yang memberikan pengaruh secara bersamaan dengan Kecerdasan Emosional Guru sebesar $33,1 \%$ dan sisanya yaitu $66.9 \%$ ditentukan oleh faktor lainnya. Koefisien regresi diperoleh $\hat{\mathrm{Y}}=28,255+0,210 \mathrm{X}_{1}+$ $0,557 \mathrm{X}_{2}$ artinya setiap peningkatan satu unit skor independen Iklim Organisasi dan Gaji secara bersamaan mempengaruhi peningkatan skor Kecerdasan Emosional Guru sebesar 0,210X $\mathrm{X}_{1}+$ $0,557 \mathrm{X}_{2}=0,767$.

Kata Kunci: Iklim Organisasi, Gaji, dan Kecerdasan Emosional Guru 


\section{PENDAHULUAN}

\section{A. Latar Belakang Masalah}

Menjadi guru adalah pekerjaan yang berat. Sebab kesulitan yang terbesar dihadapi guru bukan semata dalam hal menyampaikan materi pelajaran, tetapi dalam hal bagaimana ia mengenal dan memahami karakter dan emosi anak didiknya. Banyak kasus yang mencoreng nama guru itu karena para guru tak paham karakter siswanya, kurang sabar dalam mengajar.

Seorang guru tidak hanya memperhatikan aspek kecerdasan intelektual saja, tetapi juga aspek emosional dan spiritual. Hal ini penting mengingat seluruh aspek kecerdasan tersebut menunjang keberhasilan guru. Banyak contoh membuktikan bahwa orang yang memiliki kecerdasan intelektual saja belum tentu sukses di dunia pekerjaan.

Kecerdasan emosional atau emotional intelligence merujuk kepada kemampuan mengenali perasaan kita sendiri dan perasaan orang lain, kemampuan memotivasi diri sendiri, dan kemampuan mengelola emosi dengan baik pada diri sendiri dan dalam hubungan dengan orang lain.

Disinilah pentingnya kecerdasan emosional seorang guru, bagaimana seorang guru mampu mengendalikan emosionalnya sehingga tindakan ataupun perbuatan yang ia lakukan tidak merugikan dirinya sendiri ataupun orang lain. Mungkin terdapat beberapa faktor yang dapat mempengaruhi kecerdsan emosional guru, salah satu faktornya adalah pengaruh iklim organisasi sekolah dan kompensasi/gaji.

Iklim organisasi merupakan lingkungan manusia yang didalamnya para pegawai suatu organisasi melakukan pekerjaan mereka. Iklim organisasi menyangkut semua lingkungan yang ada atau yang dihadapi oleh pegawai yang berada dalam suatu organisasi yang mempengaruhi pegawai dalam melaksanakan kegiatan organisasinya karena lingkungan yang baik secara langsung maupun tidak langsung sangat mempengaruhi iklim organisasi. Disamping itu sebagai sistem, organisasi akan berinteraksi dengan lingkungannya.

Lingkungan dan iklim organisasi menjadi variabel penting sebab kenyataanya menunjukkan bahwa semakin banyak organisasi yang secara ilmiah memantau kekuatan lingkungan. Pemantauan ini menjadi sumber informasi yang sangat dibutuhkan untuk mengadakan perubahan dan pengembangan organisasi. Maknanya, iklim sekolah yang kondusif mempengaruhi kinerja anggota organisasi sekolah. Dengan kata 
lain, maju atau mundur sekolah bergantung pada kemampuan sekolah tersebut meciptakan lingkungannya dan kesediaan lingkungan untuk menerima keberadaanya.

Tidak sedikit terdapat lingkungan sekolah yang kurang kondusif dikarenakan keberadaannya yang dekat dengan pasar, sehingga menyebabkan ketidaknyamanan di sekitar lingkungan sekolah. Akibat ketidaknyamanan yang timbul disebabkan dengan hal itu sedikit banyaknya bisa mempengaruhi emosional siswa maupun gurunya.

Faktor berikutnya yang mungkin berpengaruh terhadap kecerdasan emosional seorang guru adalah terkait dengan kompensasi atau gaji. Setiap orang yang memperoleh gaji tinggi, hidupnya akan sejahtera. Orang akan bekerja dengan penuh antusias jika pekerjaanya mampu menyejahterakan hidupnya. Sebalik-nya, orang yang tidak sejahtera atau serba kekurangan akan bekerja tanpa gairah. Bagaimana mungkin seorang guru dapat bekerja secara professional jika berangkat dari rumah sudah dipusingkan dengan kebutuhan rumah tangga. Gaji merupakan salah satu bentuk kompensasi atas prestasi kerja yang diberikan oleh pemberi kerja terhadap pekerja.

Permasalahan gaji di beberapa daerah kota-kota kecil mungkin lebih kecil dibandingkan dengan kota-kota besar, gaji merupakan merupakan segala sesuatu yang diterima pegawai (guru) sebagai balas jasa atas kerja mereka, dan merupakan salah satu cara meningkatkan kinerja mereka. Gaji merupakan kompensasi langsung yang diterima, karena jenis kompensasi yang lain yaitu berupa tidak langsung dapat berupa tunjangan, penghargaan, apresiasi dan lain sebagainya. Terkadang amanah berupa tugas yang diterima oleh guru diawal pembelajaran tidak sebanding dengan apresiasi yang diterima oleh guru diakhir pembelajaran.

\section{B. Tujuan Penelitian}

Dengan melihat kepada permasalahan yang telah dikemukakan diatas, maka tujuan penelitian yang ingin penulis capai adalah untuk menguji hipotesis penelitian tentang ada atau tidaknya dan seberapa besar/kuat hubungan antara variabelvariabel tersebut:

1. Untuk mengetahui pengaruh iklim organisasi sekolah terhadap kecerdasan emosional guru di Yayasan Pendidikan Da'wah Ummahatul Muslimat Jakarta Timur. 
2. Untuk mengetahui gaji guru terhadap kecerdasan emosional guru di Yayasan Pendidikan Da'wah Ummahatul Muslimat Jakarta Timur.

3. Untuk mengetahui pengaruh iklim organisasi sekolah dan gaji guru terhadap kecerdasan emosional guru secara bersamasama di Yayasan Pendidikan Da'wah Ummahatul Muslimat Jakarta Timur.

\section{TINJAUAN TEORI}

\section{A. Kecerdasan Emosional}

\section{Pengertian Kecerdasan}

Kecerdasan merupakan kata benda yang menerangkan kata kerja atau keterangan. Seseorang menunjukkan kecerdasannya letika ia bertindak atau berbuat dalam situasi secara cerdas atau bodoh, kecerdasan seseorang dapat dilihat dalam caranya orang tersebut berbuat atau bertindak. ${ }^{1}$

Kecerdasan adalah kemampuan menyesuaikan diri dengan keadaan baru dengan menggunakan alat-alat berpikir. ${ }^{2}$ Dalam definisi lain yang dikemukakan oleh Howard Gadner dalam Agus Efendi kecerdasan adalah kemampuan untuk memecahkan masalah atau menciptakan sesuatu yang bernilai bagi budaya tertentu. $^{3}$

Suharsono menyebutkan bahwa kecerdasan adalah kemampuan untuk memecahkan masalah secara benar, yang secara relative lebih cepat dibandingkan dengan usia biologisnya. $^{4}$

\section{Pengertian Emosi}

Akar kata emosi adalah movere, kata kerja bahasa latin yang berarti menggerakkan, bergerak", ditambah awalan "e" untuk memberi arti "bergerak menjauh", ini menggambarkan bahwa kecenderungan bertindak merupakan hal yang mutlak dalam emosi. ${ }^{5}$ Menurut Robert K. Cooper dan Ayman sawaf dalam bukunya Agus Efendi yang berjudul "revolusi kecerdasan

${ }^{1}$ M. Alisuf Sabri, Psikologi Pendidikan, Jakarta: Pedoman Ilmu Jaya, 1996, hal. 115.

${ }^{2}$ Panitian Istilah Paedagogik DEPDIKBUD, Kamus Paedagogik, Jakarta: PT. Rajawali, 1989, hal. 146.

3 Agus Efendi, Revolusi Kecerdasan Abad 21, Bandung: Alfabeta, 2005, hal. 81 .

${ }^{4}$ Suharsono, Melejitkan Dimensi Moral Intelektual \& Spiritual, Jakarta: Inisiani Press, 2003, hal. 43.

5 Daniel Goleman, Emotional Intelligence. Terj. T. Hermaya, Jakarta: Gramedia Pustaka Utama, 1997, hal. 7. 
abad ke 21", menjelaskan bahwa kata emotion bisa didefinisikan dengan gerakan (movement), baik secara metaforis maupun literal; kata emotion adalah kata yang menunjukkan gerak perasaan. ${ }^{6}$

\section{Hakikat Kecerdasan Emosional Guru}

Inti kemampuan pribadi dan sosial yang merupakan kunci utama keberhasilan seseorang sesungguhnya adalah kecerdasan emosi. Kecerdasan emosional (EQ) adalah kemampuan untuk merasa. Kunci kecerdasan emosi adalah pada kejujuran anda pada suara hati. Tiga pertanyaan yang selanjutnya perlu diajukan adalah, apakah anda jujur pada diri sendiri? Seberapa cermat anda merasakan perasaan terdalam pada diri anda? Seringkah anda tidak mempedulikannya? Suara hati itulah yang harusnya dijadikan pusat prinsip yang mampu memberi rasa aman, pedoman, kekuatan, dan kebijaksanaan.

Kecerdasan emosional adalah kemampuan seperti kemampuan untuk memotivasi diri sendiri dan bertahan menghadapi frustasi, mengendalikan doronganhati dan dan tidak melebih lebihkan kesengangan, mengatur suasana hati dan menjaga agar beban stres tidak melumpuhkan kemampuan berfikir, berempati dan berdo'a. ${ }^{8}$

\section{B. Iklim Organisasi Sekolah}

\section{Hakikat Iklim Organisasi}

Secara etimologis kata 'iklim' dalam kamus besar bahasa Indonesia dapat memiliki dua makna, 1) keadaan hawa (suhu, kelembapan, awan, hujan, dan sinar matahari) pada suatu daerah dalam jangka waktu yang agak lama di suatu daerah; dan 2) bermakna suasana; keadaan.

Berikut beberapa pendapat ahli mengenai hakikat iklim organisasi sekolah. Menurut Davis iklim organisasi adalah lingkungan dimana para pegawai organisasi melakukan pekerjaan mereka. Iklim organisasi sebagai sistem yang dinamis dipengaruhi oleh hampir semua hal yang terjadi dalam suatu organisasi. Jadi iklim organisasi merupakan konsep sistem yang mencerminkan keseluruhan gaya hidup organisasi. Karena iklim organisasi mencerminkan gaya hidup maka secara otomatis iklim

\footnotetext{
${ }^{6}$ Agus Efendi, Revolusi Kecerdasan Abad 21..., hal. 176.

7 Ary Ginanjar, ESQ Emotional Spiritual Quotient, Jakarta: Arga publishing, 2007, hal. 9.

${ }^{8}$ Daniel Goleman, Emotional Intelligence, Terj. T. Hermaya..., hal. 43.

${ }^{9}$ http://kbbi.web.id/iklim, Diakses pada 11 Mei 2018.
} 
organisasi akan memengaruhi keseluruhan kegiatan organisasi termasuk perilaku anggotanya. ${ }^{10}$

Menurut Wirawan iklim organisasi adalah persepsi anggota organisasi (secara individual dan kelompok) dan mereka yang secara tetap berhubungan dengan organisasi mengenai apa yang ada atau terjadi dilingkungan internal organisasi secara rutin, yang mempengaruhi sikap dan prilaku organisasi dan kinerja anggota organisasi dan kemudian menentukan kinerja organisasi.

\section{Hakikat Iklim Organisasi Sekolah}

Organisasi diartikan sebagai kelompok kerja sama antara orang-orang yang diadakan untuk mencapai tujuan bersama. ${ }^{12}$ Sekolah dapat dikategorikan sebagai suatu organisasi, namun berbeda dengan organisasi lain terutama organisasi-organisasi yang berorientasi nirlaba, karena sekolah merupakan organisasi moral dan organisasi sosial. ${ }^{13}$

Sekolah sebagai sebuah organisasi dapat berjalan dan menemukan tujuannya jika terdapat sekumpulan individu yang berkerjasama dan menjalankan fungsi masing-masing, di sana terdapat pemimpin (kepala sekolah), guru, siswa, dan tenaga pendukung lainnya. Dalam menjalankan fungsinya, tiap individu tersebut saling berinteraksi satu sama lain. Kajian tentang suasana dari hubungan interaksi antar individu dalam sekolah inilah yang dibicarakan dalam iklim organisasi sekolah.

\section{Gaji}

\section{Pengertian Gaji}

Dalam kehidupan sehari-hari sering dikenal istilah gaji dan upah sehingga ada sebagian masyarakat yang menganggap sama kedua istilah tersebut, tetapi ada pula yang membedakannya. Menurut As'ad gaji sebenarnya juga upah hanya sedikit perbedaannya, gaji adalah banyaknya uang yang diterima dan sudah pasti dan waktunya selalu tepat, misalnya setiap awal bulan, seorang karyawan akan menerima sejumlah uang yang disebut gaji, sedangkan upah adalah banyaknya uang yang

\footnotetext{
${ }^{10}$ Keith Davis dan Jonh W. Newstrom, Human Behaviour at Work, Terj. Agus Dharma, Jakarta: Erlangga, 1996, hal. 21.

${ }^{11}$ Wirawan, Budaya dan Iklim Organisasi, Jakarta: Salemba Empat, 2008, hal.122.

${ }^{12} \mathrm{http} / / / \mathrm{kbbi}$.web.id/organisasi, Diakses pada 11 Mei 2018.

${ }^{13}$ Cepi Triatna, Perilaku Organisasi dalam Pendidikan, Bandung: Remaja Rosdakarya, 2015, hal. 26.
} 
diterima tidak selalu sama atau pasti dan waktunyapun tidak selalu tepat. ${ }^{14}$

Menurut Handoko gaji merupakan segala sesuatu yang diterima pegawai (guru) sebagai balas jasa atas kerja mereka, dan merupakan salah satu cara meningkatkan kinerja mereka. ${ }^{15}$ Sedangkan menurut Simamora mengemukakan bahwa gaji merupakan apa yang diterima oleh pegawai (guru) sebagai ganti kontribusi mereka kepada organisasi. ${ }^{16}$

Selanjutnya pengertian gaji menurut Hasibuan menyatakan bahwa gaji adalah balas jasa yang dibayar secara periodik kepada pegawai tetap serta mempunyai jaminan yang pasti. ${ }^{17}$ Pendapat lain dikemukakan oleh Handoko menyatakan gaji adalah pemberian pembayaran finansial kepada pegawai sebagai balas jasa untuk pekerjaan yang dilaksanakan dan sebagai motivasi pelaksanaan kegiatan di waktu yang akan datang. ${ }^{18}$

\section{Fungsi dan Peranan Gaji}

Menurut komarudin fungsi gaji bukan hanya membantu manajer personalia dalam menentukan gaji yang adil dan layak saja, tetapi masih ada fungsi-fungsi yang lain, yaitu:

a. Untuk menarik pekerja yang mempunyai kemampuan ke dalam organisasi.

b. Untuk mendorong pekerja agar menunjukkan prestasi yang tinggi.

c. Untuk memelihara prestasi pekerja selama periode yang panjang. ${ }^{19}$

Kemudian gaji juga memiliki peranan yang dimana peranan gaji ini dapat dilihat dari beberapa aspek. Menurut Poerwono peranan gaji dapat ditinjau dari dua pihak, yaitu:

a) Aspek Pemberi Kerja

b) Aspek Penerima Kerja

${ }^{14}$ Moh. As'ad, Psikologi Perusahaan, Yogyakarta: Liberty, 1995, hal. 93.

${ }^{15}$ Hani T. Handoko, Manajemen Personalia \& Sumber Daya Manusia, Edisi 2, Yogyakarta: BPEE, 1998, hal. 155.

${ }^{16}$ H. Simamora, Manajemen Sumber Daya Manusia, Edisi 2, Yogyakarta: BP STIE YKPN, 1997, hal. 540.

${ }^{17}$ M.S.P. Hasibuan, Manajemen Sumber Daya Manusia: Dasar Kunci Keberhasilan, Jakarta: Haji Masagung, 2009, hal. 118.

${ }^{18}$ Handoko T. H. Handoko, Manajemen Personalia Dan Sumber Daya Manusia, Edisi Refisi, Yogyakarta: BPFE Gajah Mada Press, 2009, hal. 218.

19 Komaruddin Sastradipoera, Manajemen Sumber Daya Manusia, Bandung: Kappa Sigma, 2009, hal. 164. 


\section{METODE PENELITIAN}

\section{A. Metode Penelitian}

Dalam penelitian ini yang dimaksudkan metode adalah cara atau jalan pengaturan dalam pemeriksaan sesuatu hal secara benar, untuk mencapai tujuan penelitian. Adapun penelitian ini menggunakan metode survei dengan pendekatan korelasional. Metode survei dipergunakan dengan pertimbangan-pertimbangan bahwa penelitian dilakukan untuk mendapatkan data dari tempat tertentu yang alamiah (bukan buatan) dengan alat pengumpul data berbentuk angket (kuesioner) test dan wawancara terstruktur dan berdasarkan pandangan dari sumber data, bukan dari peneliti.

\section{B. Populasi dan Sampel Penelitian}

\section{Populasi}

Populasi dan sampel merupakan bagian terpenting yang terdapat dalam suatu penelitian. Sebab populasi dan sampel berhubungan langsung dengan penelitian itu sendiri. Populasi adalah keseluruhan dari subyek penelitian. ${ }^{20}$ Sedangkan menurut Sugiono menyatakan bahwa populasi adalah wilayah generalisasi yang terdiri dari obyek atau subyek yang menjadi kuantitas atau karakteristik tertentu yang ditetapkan oleh peneliti untuk dipelajari kemudian untuk ditarik kesimpulannya. ${ }^{2}$

Adapun populasi dari penelitian ini adalah keseluruhan dari Guru di Yayasan Pendidikan Da'wah Ummahatul Muslimat Jakarta Timur yang meliputi guru ditingkat MD, TK, SDIT dan SMPIT dengan jumlah keseluruhan 60 orang guru.

Menurut Suharsimi Arikunto, apabila subyek yang diteliti kurang dari 100, lebih baik diambil semua sehingga penelitiannya merupakan penelitian populasi. Selanjutnya jika jumlah subyeknya besar, dapat diambil antara 10\%-15\% atau $20 \%-25 \%$ atau lebih. ${ }^{22}$

\section{Sampel}

Sampel adalah jumlah populasi yang dipilih untuk sumber data. $^{23}$ Sampel adalah sebagian dari populasi yang karakteristiknya hendak diselidiki dan dianggap mewakili

${ }^{20}$ Suharsimi Arikunto, Prosedur Penelitian Suatu Pendekatan Praktik, Jakarta: PT. Rineka Cipta, 2006, hal. 108.

${ }^{21}$ Sugiyono, Statistik Untuk Penelitian, Bandung: Alfabeta, 2007, hal. 57.

${ }^{22}$ Suharsimi Arikunto, Prosedur Penelitian Suatu Pendekatan Praktek..., hal. 112 .

23 Sukardi, Metodologi Penelitian Pendidikan, Jakarta: Bumi Aksara, 2003, hal. 54. 
keseluruhan populasi. ${ }^{24}$ Salah satu syarat yang harus dipenuhi di antaranya adalah bahwa sampel harus diambil dari bagian populasi. Sampel penelitian ialah sebagian atau wakil populasi yang diteliti atau sebagian anggota populasi yang memberikan keterangan atau data yang diperlukan dalam suatu penelitian. Dengan kata lain, sampel adalah himpunan bagian dari populasi. $^{25}$

\section{Teknik Pengambilan Sampel}

Penentuan sampel pada penelitian ini menggunakan teknik sampling jenuh. Teknik sampling jenuh ini dilakukan bila semua anggota populasi digunakan sebagai sampel. Istilah lain sampel jenuh adalah sampel sensus.

Suharsimi Arikunto menjelaskan dalam bukunya Prosedur Penelitian bahwa apabila subyeknya lebih dari 100 dapat diambil $10 \%-15 \%$ atau $20 \%-25 \%$ atau lebih. ${ }^{26}$ Mengingat jumlah populasi yang ada kurang dari 100 yakni hanya 60 guru, maka dalam penelitian ini penulis menggunakan penelitian populasi.

\section{PEMBAHASAN HASIL PENELITIAN}

Penelitian ini dilakukan dengan tujuan untuk mengetahui sejauh mana pengaruh Iklim Organisasi dan Gaji terhadap Kecerdasan Emosional guru. Dalam penelitian ini sampel yang diambil berjumlah 60 respondens dan dianalisis dengan menggunakan metode statistic melalui program SPSS 24 maka dapat dideskripsikan hasil penelitian ini sebagai berikut:

1. Pengaruh Iklim Organisasi $\left(X_{1}\right)$ terhadap Kecerdasan Emosional (Y) Guru di Yayasan Pendidikan Da'wah Ummahatul Muslimat Jakarta Timur.

Berdasarkan pengujian hipotesis menujukkan bahwa terdapat Pengaruh yang positif dan signifikan antara Iklim Organisasi $\left(\mathrm{X}_{1}\right)$ terhadap Kecerdasan Emosional (Y) Guru di Yayasan Pendidikan Da'wah Ummahatul Muslimat Jakarta Timur. Hal ini ditunjukan oleh kekuatan pengaruh atau koefisien korelasi sebesar $\mathbf{0 , 3 5 9}$ pada tingkat kepercayaan 99\% $(\alpha=0.01)$, sedangkan besarnya pengaruh atau koefisien determinasi $\mathrm{R}$ -

${ }^{24}$ Agus Suradika, Metode Penelitian Komunikasi, Jakarta: UMJ Press, 2000, hal. 37.

${ }^{25}$ M. Toha Anggoro, dkk., Metode Penelitian, Jakarta: Pusat Penerbitan Universitas Terbuka, 2004. hal.42.

${ }^{26}$ Sumarsimi Arikunto, Prosedur Penelitian Bidang Sosial Suatu Pendekatan Praktis, Jakarta: Rineka Cipta, 1992, hal. 71. 
square sebesar 0,129 yang berarti bahwa Iklim Organisasi memberikan pengaruh terhadap Kecerdasan Emosional Guru sebesar 21,9\% dan berarti sisianya 78,1\% ditentukan oleh faktor lainnya. Untuk arah pengaruh atau koefesien regresi diperoleh $\hat{\mathbf{Y}}$

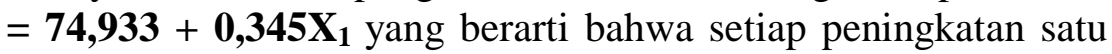
unit skor Iklim Organisasi mempengaruhi peningkatan skor terhadap Kecerdasan Emosional Guru sebesar 0,345 (korelasi cukup kuat).

2. Pengaruh Gaji $\left(\mathbf{X}_{2}\right)$ terhadap Kecerdasan Emosional Guru (Y) di Yayasan Pendidikan Da'wah Ummahatul Muslimat Jakarta Timur.

Berdasarkan pengujian hipotesis menujukkan bahwa terdapat Pengaruh yang positif dan signifikan antara Gaji $\left(\mathrm{X}_{2}\right)$ terhadap Kecerdasan Emosional (Y) Guru di Yayasan Pendidikan Da'wah Ummahatul Muslimat Jakarta Timur. Hal ini ditunjukan oleh kekuatan pengaruh atau koefisien korelasi sebesar $\mathbf{0 , 5 3 6}$ pada tingkat kepercayaan $99 \%(\alpha=0.01)$, sedangkan besarnya pengaruh atau koefisien determinasi R-square sebesar $\mathbf{0 , 2 8 8}$ yang berarti bahwa Iklim Organisasi memberikan pengaruh terhadap Kecerdasan Emosional Guru sebesar 28,8\% dan berarti sisianya $\mathbf{7 1 , 2} \%$ ditentukan oleh faktor lainnya. Untuk arah pengaruh atau

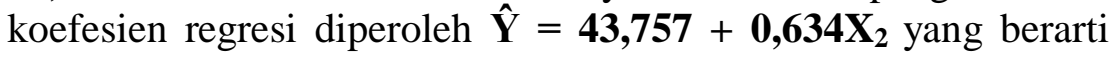
bahwa setiap peningkatan satu unit skor Iklim Organisasi mempengaruhi peningkatan skor terhadap Kecerdasan Emosional Guru sebesar 0,634 (korelasi kuat).

3. Pengaruh Iklim Organisasi $\left(X_{1}\right)$ dan Gaji $\left(X_{2}\right)$ secara Simultan terhadap Kecerdasan Emosional Guru (Y) di Yayasan Pendidikan Da'wah Ummahatul Muslimat Jakarta Timur.

Pengaruh kedua variabel independen Iklim Organisasi dan Gaji secara simultan terhadap Kecerdasan Emosional Guru menujukkan adanya pengaruh yang positif dan signifikan. Jadi pada permasalahan yang sedang diteliti diketahui bahwa secara simultan kedua variabel independen (Iklim Organisasi dan Gaji) memiliki pengaruh yang positif dan signifikan terhadap Kecerdasan Emosional Guru pada Yayasan Pendidikan Da'wah Ummahatul Muslimat Jakarta Timur.

Hal ini dapat dilihat dari kekuatan pengaruh atau koefisen korelasi $=\mathbf{0 , 5 7 5}$ yang berarti bahwa Iklim Organisasi dan Gaji secara bersamaan memberikan pengaruh terhadap Kecerdasan Emosional Guru. Sedangkan besarnya pengaruh koefesien determinasi R-square sebesar $\mathbf{0 , 3 3 1}$ yang berarti bahwa besarnya 
pengaruh Iklim Organisasi dan Gaji secara bersamaan terhadap Kecerdasan

Emosional Guru sebesar 33,1\% dan sisanya yaitu 66.9\% ditentukan oleh faktor lainnya. Adapun arah pengaruh persaman regresi $\hat{\mathbf{Y}}=\mathbf{2 8 , 2 5 5}+\mathbf{0 , 2 1 0 X _ { 1 }}+\mathbf{0 , 5 5 7 X _ { 2 }}$ yang berarti bahwa setiap peningkatan satu unit skor independen Iklim Organisasi dan Gaji secara bersamaan mempengaruhi peningkatan skor Kecerdasan Emosional Guru sebesar $\mathbf{0 , 2 1 0 X} \mathbf{X}_{\mathbf{1}}+\mathbf{0 , 5 5 7 X _ { 2 }}=\mathbf{0 , 7 6 7}$ (korelasi sangat kuat).

Jika dilihat dari nilai $\mathrm{R}$-square di atas maka secara bersama- sama variabel Iklim Organisasi dan Gaji memberikan kontribusi atau pengaruh terhadap Kecerdasan Emosional Guru pada Yayasan Pendidikan Da'wah Ummahatul Muslimat Jakarta Timur dan sisanya merupakan pengaruh faktor lain di luar kedua variabel bebas yang diteliti. Jadi meningkat dan menurunnya Kecerdasan Emosional Guru tidak hanya dipengaruhi oleh Iklim Organisasi dan Gaji saja akan tetapi bisa juga dipengaruhi oleh faktor- faktor lainnya.

Berdasarkan analisis tersebut bahwa Iklim Organisasi dan Gaji keduanya merupakan faktor yang mempengaruhi Kecerdasan Emosional Guru. Peningkatan Iklim Organisasi dan Gaji akan diikuti dengan peningkatan Kecerdasan Emosional Guru. Semakin baik kedua aspek tersebut maka tingkat Kecerdasan Emosional gurunya pun juga baik. Begitu pula sebaliknya, jika rendah aspek Iklim Organisasi dan Gaji maka tingkat Kecerdasan Emosional gurunya pun rendah.

\section{KESIMPULAN}

Berdasarkan hasil temuan penelitian yang telah dikemukakan sebelumnya mengenai pengaruh Iklim Organisasi dan gaji terhadap Kecerdasan Emosional Guru, dapat diambil beberapa kesimpulan sebagai berikut:

a. Terdapat pengaruh yang positif dan signifikan antara Iklim Organisasi dan Kecerdasan Emosional Guru di Yayasan Pendidikan Da'wah Ummahatul Muslimat Jakarta. Hal ini ditunjukan oleh kekuatan pengaruh atau koefisien korelasi sebesar $\mathbf{0 , 3 5 9}$ pada tingkat kepercayaan 99\% $(\alpha=0.01)$, sedangkan besarnya pengaruh atau koefisien determinasi Rsquare sebesar 0,129 yang berarti bahwa Iklim Organisasi memberikan pengaruh terhadap Kecerdasan Emosional Guru sebesar 21,9\% dan berarti sisianya 78,1\% ditentukan oleh faktor lainnya. Untuk arah pengaruh atau koefesien regresi 


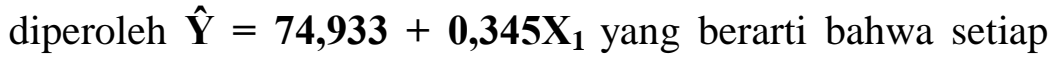
peningkatan satu unit skor Iklim Organisasi mempengaruhi peningkatan skor terhadap Kecerdasan Emosional Guru sebesar $\mathbf{0 , 3 4 5}$ (korelasi cukup kuat).

b. Terdapat pengaruh yang positif dan signifikan antara Gaji dan Kecerdasan Emosional Guru di Yayasan Pendidikan Da'wah Ummahatul Muslimat Jakarta. Hal ini ditunjukan oleh kekuatan pengaruh atau koefisien korelasi sebesar 0,536 pada tingkat kepercayaan 99\% $(\alpha=0.01)$, sedangkan besarnya pengaruh atau koefisien determinasi R-square sebesar $\mathbf{0 , 2 8 8}$ yang berarti bahwa Iklim Organisasi memberikan pengaruh terhadap Kecerdasan Emosional Guru sebesar 28,8\% dan berarti sisianya $\mathbf{7 1 , 2} \%$ ditentukan oleh faktor lainnya. Untuk arah pengaruh atau koefesien regresi diperoleh $\hat{\mathbf{Y}}=\mathbf{4 3 , 7 5 7 +}$

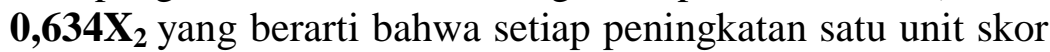
Iklim Organisasi mempengaruhi peningkatan skor terhadap Kecerdasan Emosional Guru sebesar 0,634 (korelasi kuat).

c. Terdapat pengaruh yang positif dan signifikan Iklim Organisasi dan Gaji secara bersama-sama terhadap Kecerdasan Emosional Guru di Yayasan Pendidikan Da'wah Ummahatul Muslimat Jakarta Timur. Hal ini dapat dilihat dari kekuatan pengaruh atau koefisen korelasi $=\mathbf{0 , 5 7 5}$ yang berarti bahwa Iklim Organisasi dan Gaji secara bersamaan memberikan pengaruh terhadap Kecerdasan Emosional Guru. Sedangkan besarnya pengaruh koefesien determinasi Rsquare sebesar 0,331 yang berarti bahwa besarnya pengaruh Iklim Organisasi dan Gaji secara bersamaan terhadap Kecerdasan Emosional Guru sebesar 33,1\% dan sisanya yaitu 66.9\% ditentukan oleh faktor lainnya. Adapun arah pengaruh

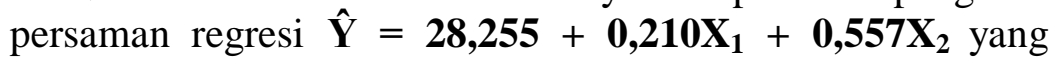
berarti bahwa setiap peningkatan satu unit skor independen Iklim Organisasi dan Gaji secara bersamaan mempengaruhi peningkatan skor Kecerdasan Emosional Guru sebesar $\mathbf{0 , 2 1 0 X} X_{1}+\mathbf{0 , 5 5 7} X_{2}=\mathbf{0 , 7 6 7}$ (korelasi sangat kuat).

\section{DAFTAR PUSTAKA}

Anggoro, M. Toha, dkk., Metode Penelitian. Jakarta: Pusat Penerbitan Universitas Terbuka, 2004.

Arikunto, Suharsimi. Prosedur Penelitian Suatu Pendekatan Praktik. Jakarta: PT. Rineka Cipta, 2006.

As'ad, Moh., Psikologi Perusahaan. Yogyakarta: Liberty, 1995. 
Daniel Goleman. Emotional Intelligence. Terj. T. Hermaya. Jakarta: Gramedia Pustaka Utama, 1997.

Davis, Keith dan Jonh W. Newstrom. Human Behaviour at Work, Terj. Agus Dharma. Jakarta: Erlangga, 1996.

Efendi, Agus. Revolusi Kecerdasan Abad 21. Bandung: Alfabeta, 2005.

Ginanjar, Ary. ESQ Emotional Spiritual Quotient. Jakarta: Arga publishing, 2007.

Handoko, T. H. Manajemen Personalia Dan Sumber Daya Manusia. Edisi Refisi, Yogyakarta: BPFE Gajah Mada Press, 2009.

Hasibuan, M.S.P. Manajemen Sumber Daya Manusia: Dasar Kunci Keberhasilan. Jakarta: Haji Masagung, 2009.

http://kbbi.web.id/organisasi , Diakses pada 11 Mei 2018.

Sabri, M. Alisuf. Psikologi Pendidikan. Jakarta: Pedoman Ilmu Jaya, 1996.

Sastradipoera, Komaruddin. Manajemen Sumber Daya Manusia. Bandung: Kappa Sigma, 2009.

Simamora, H. Manajemen Sumber Daya Manusia, Edisi 2. Yogyakarta: BP STIE YKPN, 1997.

Sugiyono. Statistik Untuk Penelitian. Bandung: Alfabeta, 2007.

Suharsono. Melejitkan Dimensi Moral Intelektual \& Spiritual. Jakarta: Inisiani Press, 2003.

Sukardi. Metodologi Penelitian Pendidikan. Jakarta: Bumi Aksara, 2003.

Suradika, Agus. Metode Penelitian Komunikasi. Jakarta: UMJ Press, 2000.

Triatna, Cepi. Perilaku Organisasi dalam Pendidikan. Bandung: Remaja Rosdakarya, 2015.

Wirawan. Budaya dan Iklim Organisasi. Jakarta: Salemba Empat, 2008. 